In this issue:

Toward Guidelines for Bibliographic Instruction in Academic Libraries

Inside Washington

News From the Field

Draft: Access Policy Guidelines

People

Classified Advertising

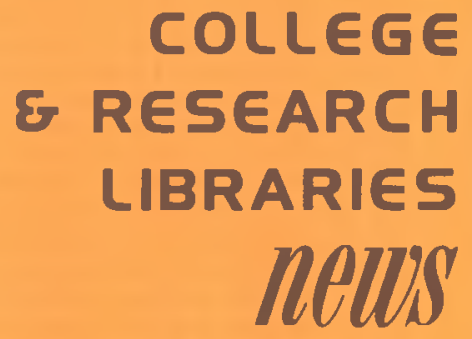

NO. 5 - MAY 1975

\title{
Toward Guidelines for Bibliographic Instruction in Academic Libraries
}

The following document is the beginning of an effort by the ACRL Bibliographic Instruction Task Force to provide a useful statement on bibliographic instruction. The present edition begins with a general statement of guidelines for what constitutes an effective bibliographic instruction program. The second portion of the document is a model statement of objectives for bibliographic instruction for undergraduates.

The committee intends to expand this document in the future to include other model statements and concrete descriptions of segments of a quality library instruction program. These additional statements will amplify the guidelines statement with which this draft begins. The contents of these statements will include (1) model written profiles of information needs of academic community groups, (2) model bibliographic instruction program goals and timetable for implementation, (3) model evaluation programs, including questionnaire forms and tests, and procedures, and (4) detailed statements on facilities, equipment, and materials needed for bibliographic instruction.

The task force welcomes comment on these statements, which should be directed to the chairman of the committee, Thomas Kirk, Box E-72, Earlham College, Richmond, IN 47374. Other members of the task force include: Elizabeth Butler, Juan R. Freudenthal, Stefania A. Koren, Anne B. Passarelli, Hannelore B. Rader, Dennis E. Robison, and Sara Lou Whildin.

\section{GUIDELINES FOR BIBLIOGRAPHIC INSTRUCTION IN ACADEMIC LIBRARIES $^{1}$}

The Association of College and Research Libraries Bibliographic Instruction Task Force recognizes that it is a responsibility of an academic library not only to support the teaching function of its parent institution but also to actively participate in that function. A basic responsibility of an academic library is to instruct the cornmunity in the effective identification and use of information resources relevant to their needs and interests. To meet ACRL recognized standards of library service, each academic library shall provide an effective program of instruction to its community as one of its major public services. Effective instructional programs will be characterized by:

1. A written profile of the information needs of various segments of the academic community.

2. A written statement of objectives of instruction which:

a. will include long-range and immediate goals with projected timetables for implementation.

b. will be directed to specific identified needs within the academic community and make provisions for various methods of instruction to all segments of the academic community who have a need to use library facilities and services.

c. outline methods by which progress to- 
ward the attainment of instructional objectives can be measured. Methodology must provide for measures of academic community learning, academic community attitudes, and cost effectiveness of instruction.

3. Continuing financial support:

a. clearly identifiable within the library's budget programs and statements.

b. sufficient to provide for the professional and supportive staff, equipment, materials, and facilities necessary to attain the delineated objectives.

4. Librarians and other qualified staff responsible for planning, implementing, and evaluating the program:

a. inclusive of persons with training in: various academic disciplines, the identification and use of library resources, teaching skills, preparation and use of audiovisual and other teaching materials, preparation and use of evaluative instruments, clerical skills.

b. in sufficient numbers necessary to attain the delineated objectives.

c. clearly identifiable and of a status similar to persons responsible for planning, implementing and evaluating the other major functions of the library.

5. Facilities, equipment, and materials available to accommodate the preparation of instructional materials and the presentation of various modes of instruction (individual, small group, large group, lecture, discussion, media, etc.); of sufficient number, size, and scope to accommodate the attainment of the delineated objectives.

6. Academic community and library community participation in the formulation of objectives and the evaluation of their attainment.

7. Attainment of written objectives for a fiveyear period.

The written statement of objectives identified in 2 is a significant element in an effective instructional program; it of necessity must be unique to each institution and be the product of that institution. The statement of objectives which the ACRL Bibliographic Instruction Task Force has prepared is appended and is intended to serve as a model which individual libraries should review and adopt to their purposes.

\section{ACADEMIC BIBLIOGRAPHIC INSTRUCTION: MODEL STATEMENT OF OBJECTIVES}

\section{by ACRL Bibliographic Instruction Task Force}

While reviewing the model statement, a few points should be kept in mind:
1. The model statement's primary purposes are to (a) get academic librarians to focus on and articulate what their instructional objectives should be and to design instructional programs to achieve these objectives and (b) stimulate research into whether existing programs are achieving these objectives.

2 . The objectives are those for an entire program of bibliographic instruction in an academic institution.

3. The objectives are intended to cover bibliographic instruction programs for undergraduates. Some objectives are no doubt applicable to any level of student, but these objectives in their totality are intended to speak specifically to the needs of undergraduates.

4. The objectives do not suggest one method of instruction nor should they be used for evaluating a particular instruction unit.

5. An attempt has been made to write the enabling objectives (E's) as behavioral objectives. ${ }^{2,}{ }^{3}$ In any institution's revision or individually written objectives, the objectives should be specific and measurable.

6. The arrangement of the terminal objectives and the related enabling objectives is not intended to suggest a sequence for an instructional program nor is it intended to suggest an order of significance. The task force has debated extensively whether the objectives should include aspects of what has commonly been called orientation in what is supposed to be a statement on bibliographic instruction. While the task force is absolutely convinced

News items for inclusion in C\&RL News should be sent to Mary Frances Collins, Assistant Director of Libraries for Technical Services, University Library ULB-35A, State University of New York at Albany, 1400 Washington Are., Albany, NY 12222. Advertising (including classified ads) should be sent to Leona Swiech, Advertising Office, American Library Association, 50 E. Huron St. Chicago, IL 60611 . Production and circulation matters are handled by ALA Central Production Unit, at the above address.

News editor: Mary Frances Collins, Assistant Director of Libraries for Technical Services, State University of New York at Albany, Albany. Associate News editor: Anne Dowling, Assistant Librarian Acquisitions Department, Library, State University of New York at Albany. Editor: Richard D. Johnson, Milne Library, State University College, Oneonta, New York 13820. President. ACRL: H. William Axford. Exacutive Secratary. ACRL: Deverly P. Lynch.

College \& Research Libraries is published by the Association of Collega and Research Libraries, a division of the American Library Association, 17 times yearly $\rightarrow$ bimonthly journal issues and II monthly (combining July-August) News issues-at I20I-05 Bluff St., Fulton, MO 6525I. Subscription, $\$ 15.00$ a year, or to members of the division, \$7.50, included in dues. Second-class postage paid at Fulton, Missouri 6525I.

(C) American Library Association 1975. All material in this journal subject to copyright by the American Library Association may be photocopied for the noncommercial purpose of scientific or educational advancement. 
that orientation is not sufficient, neither are we convinced that meaningful instruction can be divorced from orientation to a particular library.

7. The task force believes that the primary role of bibliographic instruction is to provide students with the specific skills needed to successfully complete their assignments. But in addition, bibliographic instruction should also serve the more general function of preparing students to make effective life-long use of the library regardless of specific course work. Individual librarians or library staffs must use all of their skills to develop an instruction program that achieves these or revised objectives in the context of the students' course and library use.

The model statement is composed of a series of terminal objectives ( $11, \mathrm{~T} 2, \mathrm{~T} 3 \mathrm{a}, \mathrm{T} 3 \mathrm{~b}$, etc.) written during 1973. These objectives have received the careful attention of the task force and other librarians involved in library instruction. Since October 1973, the task force has been working on the enabling objectives (E1, $\mathrm{E} 2$, etc.) which are listed under each terminal objective. The final version was approved by the committee at its meeting during the American Library Association conference in July 1974.

\section{OBJECTIVES}

General objective:

A STUDENT, BY THE TIME HE OR SHE COMPLETES A PROGRAM OF UNDERGRADUATE STUDIES, SHOULD BE ABLE TO MAKE EFFICIENT AND EFFECTIVE USE OF THE AVAILABLE LIBRARY RESOURCES AND PERSONNEL IN THE IDENTIFICATION AND PROCUREMENT OF MATERIAL TO MEET AN INFORMATION NEED.

T1. The student recognizes the library as a primary source of recorded information.

E1. Given a list of information needs and services which can be best handled by a variety of campus units, the student correctly identifies the library as the best unit for at least $85 \%$ of the appropriate listings. For example, given a list of $\mathbf{2 5}$ information needs or services of which 14 are best handled by the library, the student correctly suggests the library for 12 of those 14 items.

T2. The student recognizes the library staff, particularly the reference staff, as a source of information, and is comfortable seeking assistance from staff members.

- An asterisk beside a number indicates that the task force does not recommend the exact value indicated; it is only suggestive.
E1. Given a map of the library, the student is able to locate key service points (e.g., circulation, reserve, periodicals). The student can identify the location of information and/or reference area(s) of the library.

E2. The student can identify the members of the reference staff by sight and locate their offices.

E3. (If applicable) the student can identify by name the member(s) of the reference staff best qualified to assist him in his subject major.

E4. The student asks the reference staff for assistance whenever library-related information is needed.

E5. When asked about library services, the vast majority of students will respond positively to questions such as: "Are there people within the library who are willing to give assistance in locating needed information?" "Do these people give competent assistance?"

T3. The student is familiar with (or has knowledge of) the library resources that are available to him.

a. The student knows what library units exist on his campus and where they are located. The student knows what major information resources and collections are available in these units.

E1. While seeking information from the library, students will use most campus library units which contain substantial material relevant to their topic.

E2. While using the library, students will use a variety of collections within the central library: documents, pamphlet file, microfilm, etc., as appropriate to their topic.

b. The student understands the procedures established for using these facilities.

E1. A student can sign out a library item correctly (as defined by each institution).

E2. The student can interpret library forms (e.g., overdue notices, search forms, hold requests, etc.).

c. The student knows about the off-campus information facilities available and how to approach their resources.

E1. A student will ask the reference staff for advice about the possibilities of other information resources outside the "official libraries" of his college or university when those sources do not meet his needs.

E2. A student who has need of materials which the library does not

Continued on page 169 


\section{Interested in Where You Stand?}

The Association of Research Libraries (ARL) has established quantitative criteria which determine eligibility for ARL membership. The criteria are based on ten of the statistical categories used by the association in its annual statistics. Each year medians are established for these categories. To qualify for automatic invitation to membership, a university library must have maintained for a three-year period an average of over 50 percent of the current medians of the first eight categories, and an average of over 40 percent of the last two. With the publication of the 1973-1974 statistics, the median figures and the minimum number required for the current year for each statistical category are now available as noted below:

$\begin{array}{cc} & \text { Median } \\ \text { Categories } & 1973-1974\end{array}$

Volumes in library

Volumes added-gross

$\begin{array}{rr}1,553,192 & 776,596 \\ 78,671 & 39,335 \\ 65 & 32 \\ 191 & 95 \\ \$ 1,172,990 & \$ 586,495 \\ \$ 1,865,171 & \$ 932,585 \\ \$ 3,243,492 & \$ 1,621,746 \\ 19,343 & 9,671 \\ 231 & 92 \\ 44 & 18\end{array}$

Number of professional staff, FTE

Number of total staff, FTE

Expenditures: materials \& binding

Expenditures: salaries \& wages

Total operating expenditures

Number of current periodicals

Number of Ph.D.s awarded

Fields in which Ph.D.s are awarded

44

Required

-Association of Research Libraries Newsletter No. 76 (December 30, 1974).

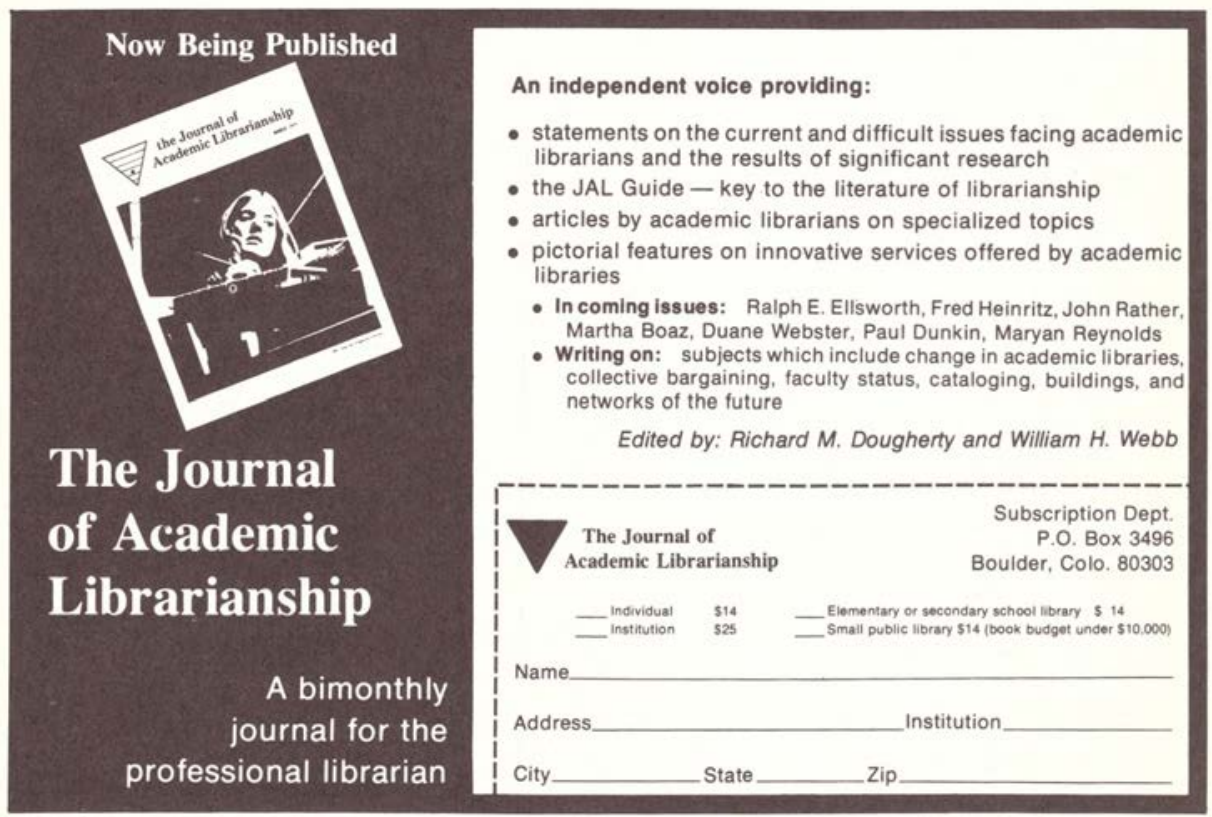


4.4.4 Display space.

4.4.5 Special fee-based services (e.g., access to computerized bibliographic data bases).

\section{References}

1. Goal and Objectives of the American Library Association, as adopted by the Council of the American Library Association. January $24,1975$.

2. "A National Program for Library and Information Services." 2d Draft (Rev.) Prepared by the National Commission on Libraries and Information Science. September 15,1974 . Washington, D.C.

\section{Guidelines}

Continued from page 139

have will request that they be borrowed from another library.

T4. The student can make effective use of the library resources available to him.

a. He knows how to use institutional holdings records (such as the card catalog and serials holdings lists) to locate materials in the library system.

E1. Given a map of the library, the student can correctly identify the location of the library's catalog (e.g., card catalog, book catalog, public shelf list) and other holdings lists in $3^{*}$ minutes.

E2. The student will correctly identify and explain the purpose of selected elements on a sample cata$\log$ entry in $5^{\circ}$ minutes. The selected elements will include: the author, title, place of publication, publisher, date of publication, series title, bibliographic notes, tracings, and call number.

E3. Given a topic or list of topics, the student will accurately list the items found in the catalog on those topics in a specified period of time. The topics will include items which require the student to use the U.S. Library of Congress Subject Headings Used in the Dictionary Catalog of the Library of Congress. The student will also have to demonstrate his knowledge of form subdivisions, and subject filing rules such as

* An asterisk beside an item indicates that the task force does not recommend it; it is only suggestive. historical subdivisions are filed in chronological order.

E4. Given a list of materials, the student, in a specified time, can correctly identify and locate those materials which the library owns. The list shall include incomplete citations, citations which are listed under entries other than the "main entry." It will also include:

Book (individual author)

Book (corporate or institutional author)

Journal (recent issue)

Journal (older or discontinued title)

Newspaper

U.S. Document

Pamphlet

Non-book materials

Microform

Other, as appropriate to the institution

This list will include items which require the student to demonstrate his knowledge of selected filing rules such as: initial articles are ignored in filing, abbreviations are filed as if spelled out, $\mathrm{Mc}$ is filed as if spelled Mac, numerals are filed as if spelled out.

b. He knows how to use reference tools basic to all subject areas.

E1. Given a map of the library, the student can correctly identify the location of the reference department (and its catalog) in a specified time period.

E2. In a specified time period, the student can identify major reference tools (encyclopedia, dictionary, index) in an unfamiliar field using a guide to the literature such as Winchell's Guide to Reference Books.

E3. In a specified time period, the student can list five periodical titles (and the indexes which cover them) in an unfamiliar subject field using a directory such as Ulrich's International Periodical Directory.

E4. In a specified time period, the student will list five titles available on an unfamiliar topic using a bibliography such as Subject Guide to Books in Print, Bibliographic Index, Library of Congress, Books: Subjects.

E5. Given a topic with which the student is unfamiliar, in a specified time period, he will locate a gen- 
eral introduction to that topic and at least two references to further information using an encyclopedia. The topic as stated should require the use of the encyclopedia's index to locate relevant materials.

E6. Given a sample entry, the student will correctly identify selected elements of a typical periodical index entry in a specified period of time. These elements will include: title of article, title of journal, volume, date, author, pages.

E7. Given a list of topics and a list of indexes (such as Reader's Guide, SSHI, ASTI, PAIS), the student will select the index which best covers each topic. At least $85 \%$ of the students' selections should be correct.

E8. Given the author and title of a book, the student will locate a review of that book in a specified time period using a book review index such as Book Review Digest, and Book Review Index.

E9. Given a specific topic of current interest, in a specified time period, the student will locate two news-

\section{New from Faxon}

\section{Serials Updating Service Annual}

\begin{abstract}
The first Serials Updating Service Annual is an alphabetical cumulation of Volume 1 , issue 1-15 (1973-74) of the Serials Updating Service Quarterly newsletter. The Annual provides, in a single source, a year's record of changes in title, frequency, etc. and bibliographic irregularities such as additional volumes, delays in publication, etc. This information will be of valuable assistance to the various library departments: acquisitions, serials records, reference, and binding.
\end{abstract}

The price of the Annual is \$10. Place your order today.

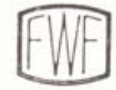

\section{f.W. FaXON COMPANY,InC.}

Publishing Division

15 Southwest Park, Westwood, MA 02090 paper articles on that topic using a newspaper index such as the New York Times Index.

${ }^{\circ} \mathrm{E} 10$. Given the name of a witness who has appeared before a Congressional Committee, the student can locate a complete citation to that testimony using CIS Index in a specified time period.

'E11. Given a topic of recent concern to the federal government, the student can locate citations to information issued by both the Executive and Congressional branches using the CIS Index and/or the Monthly Catalog.

'E12. Given a specific need for statistical information on the U.S., the student can locate the requested statistics and identify the agency publication from which the statistic was taken using Statistical $A b$ stract of the United States in a specified time period.

c. The student knows how information is organized in his own field of interest and how to use its basic reference tools.

d. The student can plan and implement an efficient search strategy using library, campus, and other resources as appropriate.

e. The student is able to evaluate materials and select those appropriate to his needs.

E1. Given a topic within his major field of interest, in a specified time period, the student will compile a quality bibliography using an efficient search strategy and keep a diary of his search. A

- An asterisk beside an item indicates that the task force does not recommend it; it is only suggestive.

\section{New Science Editor for Choice}

Choice wishes to announce the appointment of Joseph Helfer as assistant editor for science and technology. Mr. Helfer received his undergraduate education at Bard College and his master's degree in physics from Wesleyan University. He has most recently been on the staff of the Connecticut State Department of Environmental Protection. He replaces Kenneth I. Werner, who has resigned to accept a position as science acquisition editor with Cambridge University Press. 
librarian and/or classroom faculty member will judge the quality of the bibliography on the following factors:

(1) $80 \%$ of the entries shall meet one or more of the following criteria:

(a) be written by recognized authorities in the field.

(b) be represented in standard bibliographies on the topic.

(c) appear in a recognized journal in the field.

(2) bibliographic format will conform to accepted standards in that subject field.

A librarian will judge the efficiency of the search strategy as evidenced in the diary. The diary should evidence:

(1) The student clearly defined his topic before or during the initial stages of the search.

(2) The student considered and effectively used alternative search terms throughout his search.

(3) The student consulted an encyclopedia or handbook or other general source to obtain standard data or information on his topic early in his search.

(4) The student searched for and used available bibliographies on his topic.

(5) The student searched relevant indexes, or abstracts to update his information.

(6) The student used the subject card catalog.

(7) The student used bibliographies and/or footnotes in relevant materials found during his search.

(8) The student used book reviews, biographical aids or other sources to help him evaluate materials.

(9) The student made accurate complete bibliographic notes and avoided repeated searches to locate or check citations.

(10) The student located materials

\section{ACRL Membership}

March 31, 1975

13,545

March 31, 1974

11,520

March 31, 1973 of interest to him outside the library.

(11) The student consulted librarians and faculty members for aid and suggestions whenever appropriate.

\section{REFERENCES}

1. Bibliographic instruction is defined here to mean instruction in the bibliographic apparatus available in the library and their effective and efficient use. While an orientation program which covers a particular physical facility is necessary at each academic institution, the ACRL Bibliographic Instruction Task Force is concerned primarily with the use of the bibliographic structure housed in the library.

2. General objective is the overall goal of the program; terminal objectives break the general objectives down into specific meaningful units; and enabling objectives define the specific knowledge or skills which are necessary to achieve the terminal objectives. The terminology comes from the Commission on Instruction Technology's report in To $\mathrm{Im}$ prove Learning v.2 (Bowker, 1970), p.944.

3. Julie S. Vargas, Writing Worthwhile Behavioral Objectives (New York: Harper, 1972), 175p.

\section{You have your own personal supervisor
Stechert Macmillan}

Do you have a question? A problem? Pick up the phone. Write. You'll always have a friendly expert familiar with the specific problems of your library to consult with.

In fact, your personal representative has a world. wide staff of librarians, bibliographers and linguists at his beck and call for domestic and foreign acquisitions.

Phone or write now and we'll give you complete details.

$$
\text { Let's talk! }
$$

\section{STECHERT MACMILAN, INC. INTERNATIONAL ACQUISITION SERMICES Serving Libraries Since 1872}

866 Third Avenue • New York, N.Y. 10022 (212) $935-4251$

NEW YORK • LONDON • PARIS • STUTTGART

Periodical Subscription Service - Continuation/Serial Service Monographic Books for Academic. Research and Popular Libraries 